\title{
PENGARUH PERKEBUNAN KELAPA SAWIT TERHADAP KUANTITAS AIR DENGAN PENDEKATAN NERACA AIR TANAMAN (STUDI KASUS DI PT. REZEKI KENCANA)
}

\author{
Inge Meitasari ${ }^{1}$, Asripin Aspan ${ }^{2}$, Robby Irsan ${ }^{1}$ \\ ${ }^{1}$ Program Studi Teknik Lingkungan, Universitas Tanjungpura, Indonesia \\ ${ }^{2}$ Program Studi IImu Tanah, Universitas Tanjungpura, Indonesia \\ E-mail: inge_meitasari@yahoo.co.id
}

\begin{abstract}
ABSTRAK
Kelapa sawit menjadi komoditas primadona dunia, akan tetapi konsekuensinya adalah perambahan dan konversi hutan yang tidak dapat dielakkan. Adanya perubahan penggunaan lahan akan mengubah sistem dan tatanan neraca air yang ada di wilayah gambut tersebut. Penelitian ini mengkaji nilai tatanan neraca air dengan melakukan penelitian terhadap perbandingan nilai kuantitas air khususnya surplus dari neraca air tanaman antara lahan perkebunan kelapa sawit dengan lahan hutan. Model neraca air tanaman yang dipergunakan adalah neraca air lahan Thorthwaite \& Mather (1957) yang telah dimodifikasi. Nilai surplus pada lahan perkebunan sawit $1.091 \mathrm{~mm}$, sementara pada lahan hutan konversi sebesar $1.151 \mathrm{~mm}$. Maka langkah yang dilakukan oleh manajemen perkebunan adalah dengan mempertahankan wilayah konservasi sebagai penampung alami, rorak untuk meningkatkan infiltrasi air ke dalam tanah dan membuat embung besar.
\end{abstract}

Kata kunci: Neraca air tanaman, kelapa sawit, lahan gambut.

\section{ABSTRACT}

Palm oil is become the belle of world commodity, however enroachment and conversion of forest can't be avoided. The change of land use will change the system and water balance in peat area too. This study research about the value of water balance to compare the value of water quantity, particullarly water surplus from water balance between palm oil area and land of forest. Water balance that used by Thorthwaite \& Mather (1957), is apply for this study which had been modification. The value of surplus in palm oil area is $1.091 \mathrm{~mm}$, while in land of conversion forest is $1.151 \mathrm{~mm}$. Availibility of water in area, have to guarantee by the management of farm to maintain area of conservasion as natural reservoir, rorak to increase water infiltration into soil and make ponds.

Keywords: Balance of plant water, palm oil, peatlands.

\section{Pendahuluan}

Kelapa sawit merupakan salah satu komoditas yang menjadi primadona dunia. Dalam dua dekade tersebut bisnis sawit tumbuh diatas $10 \%$ per tahun, jauh meninggalkan komoditas perkebunan lainnya yang tumbuh dibawah $5 \%$. Kecenderungan tersebut semakin mengerucut, dengan ditemukannya hasil-hasil penelitian terhadap deversifikasi yang dapat dihasilkan oleh komoditi ini, selain komoditi utama berupa minyak sawit, sehingga menjadikan komoditi ini sangat digemari oleh para investor perkebunan. Akan tetapi konsekuensinya adalah perambahan dan konversi hutan yang tidak dapat dielakkan.

Dan menurut penelitian Harahap dan Darmosarkoro (1999), mengemukakan bahwa kelapa sawit memerlukan air berkisar 1.500-1.700 mm setara curah hujan per tahun untuk mencukupi kebutuhan pertumbuhan dan produksinya, dibanding tanaman keras atau perkebunan lainnya kelapa sawit memang termasuk tanaman yang memerlukan ketersediaan air relatif banyak. Kebutuhan air kelapa sawit hampir sama dengan kebutuhan air untuk tebu yaitu 1.000-1.500 mm per tahun dan pisang 700-1.700 mm per tahun, tetapi tidak setinggi kebutuhan air untuk tanaman pangan berkisar $1.200-$ $2.850 \mathrm{~mm}$ per tahun atau per 3 musim tanam, seperti padi, jagung, dan kedelai (Pasaribu, dkk, 2012). 
Untuk perkebunan kelapa sawit (oilpalm plantation) ini sendiri merupakan perkebunan yang tengah berkembang di Kabupaten Kubu Raya. Data yang diambil dari Badan Pusat Statistik Kabupaten Kubu Raya menyebutkan luas areal perkebunan kelapa sawit pada tahun 2010 mencapai $44.536 \mathrm{Ha}$. Dengan luas Kabupaten Kubu Raya sekitar $\pm 698.524 \mathrm{Ha}$, potensi sumber daya lahan yang ada sangat mendukung untuk dikembangkannya komoditi sejenis. Dengan letak geografis yang dekat dengan pusat perdagangan, serta karakteristik perekonomian yang bersifat agraris-industri, sangat potensial untuk dikembangkan perkebunan kelapa sawit. Kecamatan Sungai Ambawang merupakan sentral pertumbuhan dan perkembangan utama areal perkebunan kelapa sawit di Kabupaten Kubu Raya. Luas areal perkebunan kelapa sawit di kecamatan ini mencapai 21.076 Ha pada tahun 2010 (Badan Pusat Statistik, 2010).

Salah satu perkebunan kelapa sawit yang terdapat di Kabupaten Kubu Raya, tepatnya di kecamatan Teluk Pakedai yaitu PT Rezeki Kencana. Kecamatan Teluk Pakedai ini merupakan salah satu daerah pengembangan untuk perkebunan kelapa sawit. PT Rezeki Kencana ini terletak di Desa Deras Kecamatan Teluk Pakedai Kabupaten Kubu Raya dan memiliki luas areal \pm 3.770,95 Ha. Perkebunan ini tumbuh di lahan gambut, dimana dengan ketebalan gambut rata-rata kurang dari 3 meter. Secara geografis wilayah Kecamatan Teluk Pakedai terletak pada posisi $00^{\circ} 17^{\prime} 35^{\prime \prime}$ LS $00^{\circ} 34^{\prime} 56,38^{\prime \prime}$ LS dan 109¹0’35” BT - 109¹9'37” BT. Jumlah penduduk Kecamatan Teluk Pakedai, pada tahun 2011 berjumlah 19.064 jiwa. Topografi tempat bermukim penduduk di wilayah ini sebagaian besar berupa dataran yang relatif datar. Pada umumnya struktur tanah terdiri dari tanah organosol.

Dengan kondisi fisiografis Kabupaten Kubu Raya sebagian besar berada pada lahan gambut, menjadi tantangan bagi pengembangan kelapa sawit secara optimum. Dengan diberlakukannya Permentan No. 14 tahun 2009 tentang Pedoman Pemanfaatan Lahan Gambut untuk Budidaya Kelapa Sawit, pemanfaatan lahan gambut menjadi urgen sehubungan dengan fungsi lahan gambut untuk aspek konservasi dan mencegah degradasi lahan gambut. Kabupaten Kubu Raya berdasarkan Peta Jenis Tanah, memiliki luas lahan gambut \pm 342.984 ha atau $\pm 49,1 \%$ dari luas total kabupaten Kubu Raya. Dari total luas lahan gambut tersebut, pengembangan lahan gambut untuk tanaman kelapa sawit, menurut Pedoman Pemanfaatan Lahan Gambut Peraturan Menteri Pertanian No. 14 tahun 2009, terutama pada lahan gambut dengan kedalaman kurang dari tiga meter (gambut dangkal, dan gambut sedang), dan pada kawasan APL. Berdasarkan ketentuan tersebut, maka luas lahan gambut yang dapat dimanfaatkan untuk pengembangan kelapa sawit adalah seluas \pm 102.934 ha atau $14,74 \%$ dari luas total Kabupaten Kubu Raya (Krisohadi, 2011).

Dampak dari perubahan lahan hutan menjadi perkebunan kelapa sawit tersebut dapat berupa hal yang positif ataupun negatif, untuk mengetahui implikasi dari hal ini maka perlu dilakukan penelitian mengenai perbandingan kuantitas air melalui perhitungan neraca air tanaman.

\section{Metodologi Penelitian}

Observasi lapangan dilakukan pada rentang bulan Juli sampai dengan September 2013. Tempat pengambilan data primer terletak pada areal milik PT. Rizki Kencana yang berada di Desa Deras Kecamatan Teluk Pakedai Kabupaten Kubu Raya. Lahan yang ditinjau yaitu lahan perkebunan kelapa sawit dan lahan hutan konversi.

\section{a. Data}

Data primer didapat dari hasil pengamatan langsung ke lapangan, yaitu di lokasi perkebunan kelapa sawit dengan cara menguji hasil sampel tanah untuk menentukan KL (kapasitas lapang) dan TLP (titik layu permanen). Dan untuk data sekunder meliputi data curah hujan, suhu, kelembaban udara, lama penyinaran, iklim, kecepatan dan arah angin, yang didapat dari BMG Supadio serta informasi umum mengenai luasan lahan yang didapat dari PT. Rezeki Kencana.

\section{b. Neraca Air Tanaman}

Model ini merupakan penggabungan data klimatologi, data tanah dan data jenis tutupan lahan yang ada. Data klimatologi yang digunakan yaitu rentang periode 2002-2012. Untuk data tanah 
berupa KL (kapasitas lapang) dan TLP (titik layu permanen). Dan untuk data tanaman yang digunakan adalah data koefisien tanaman (kc). Tanaman tutupan lahan (landcover) dibagi menjadi dua bagian, yaitu perkebunan kelapa sawit dan hutan konversi. Asumsi yang digunakan dalam penelitian ini adalah untuk landcover perkebunan kelapa sawit yaitu berupa tanaman kelapa sawit dan tidak ada tanaman lain yang tumbuh pada lahan perkebunan kelapa sawit tersebut serta memiliki umur tanaman lebih dari 7 tahun. Sedangkan landcover hutan konversi yaitu berupa lahan berhutan atau areal yang ada tegakannya, dan lahan ini sewaktu-waktu bisa dibuka untuk keperluan lain misalnya perkebunan.

Model neraca air tanaman yang dikembangkan oleh Thorthwaite dan Mather (1957) adalah sebagai berikut:

1. Curah hujan

Nilai curah hujan, diperoleh dari Stasiun Meterologi Pontianak. Curah hujan digunakan yaitu nilai curah hujan bulanan dari tahun 2002-2012.

2. Curah hujan peluang $75 \%$

Nilai curah hujan peluang kejadian $75 \%$ ( $P>75 \%$ ) yaitu diperoleh dari hasil perhitungan dengan menggunakan metode ranking.

3. $\mathrm{ET}_{0}$ (Evapotranspirasi acuan)

Nilai evapotranspirasi standar harian $\left(\mathrm{ET}_{0}\right)$ diperoleh menurut metode empiris PenmanMonteith dengan menggunakan software Cropwat versi 8.0. Nilai $\mathrm{ET}_{0}$ ini berdasarkan data suhu udara, kecepatan angin, kelembaban udara, penyinaran matahari dan radiasi.

4. Kc (crop coefisien)

Nilai coefisien crop $(\mathrm{kc})$ yaitu koefisien tanaman yang diperoleh secara empiris dari percobaan di lapang yang bersifat khusus untuk setiap jenis tanaman dan berubah menurut fase perkembangan tanaman.

Nilai kc rata-rata untuk jenis hutan adalah 0,87 - 0,89 (Shuttleworth, 1988; dalam Van de Wert, 1994; dalam Widodo, 2010), sedangkan untuk tanaman kelapa sawit adalah sebesar 0,93 untuk tanaman kelapa sawit yang berumur lebih dari 7 tahun (Harahap, 1999; dalam Widodo, 2010).

5. ETc (Evapotranspirasi Potensial)

Nilai ETc (evapotranspirasi pertanaman) bulanan diperoleh berdasarkan hasil kali antara koefisien tanaman dengan evapotranspirasi standar.

$\mathrm{ETc}=\mathrm{kc} \times \mathrm{ET}_{0}$

6. $\mathrm{CH}-\mathrm{ETC}$

Nilai CH - ETc diperoleh dari pengurangan curah hujan peluang kejadian $75 \%$ dengan evapotranspirasi pertanaman.

7. APWL (Accumulation of Potensial Water Loss)

Nilai APWL (Accumulation of Potensial Water Loss) diisi dengan nilai negatif dari pengurangan curah hujan $(\mathrm{P}>75 \%)$ dengan evapotranspirasi pertanaman yang diakumulasikan bulan demi bulan.

8. KAT (Kandungan Air Tanah)

Untuk mengisi baris ini, terlebih dahulu menentukan nilai kapasitas lapang (KL) dan titik layu permanen (TLP) tanah yang bersangkutan serta kedalaman tinjaunya. Nilai KL dalam satuan $\mathrm{mm}$. Nilai KL dan TLP (\%) pada skala pF 2,4 dan 4,2 setara dengan $\mathrm{cm} / \mathrm{m}$ atau $10 \mathrm{~mm} / \mathrm{m}$.

Mengisi nilai KAT tabel komputasi, berdasarkan APWL, mulai dari bulan pertama APWL (permulaan bulan kering) hingga APWL bulan terakhir, dengan cara sebagai berikut :

$\mathrm{AT}=\mathrm{KL}-\mathrm{TLP}$, dimana $\mathrm{AT}=$ air tersedia, $\mathrm{TLP}=$ titik layu permanen dan $\mathrm{KL}=$ kapasitas lapang

$\mathrm{KAT}=\mathrm{TLP}+\left[[1,00041-(1,07381 / \mathrm{AT})]^{\mid A P W L} \times \mathrm{AT}\right]$

Lanjutkan pengisian KAT dengan menambah nilai KAT bulan terakhir dengan nilai positif $(\mathrm{CH}-$ ETp) bulan berikutnya, hasilnya adalah KAT bulan berikut. Hal ini dilakukan apabila tidak terjadi APWL dibulan tersebut. Teruskan penjumlahan tersebut hingga KAT maksimum, yaitu kapasitas lapang atau KAT $=\mathrm{KL}$

Mengisi KAT = KL hingga bulan terakhir. Apabila nilai KAT mencapai nilai kapasitas lapang. 
9. $\mathrm{dKAT}$

Baris perubahan KAT atau dKAT diperoleh dari rumus:

$\mathrm{dKAT}=\mathrm{KAT}_{1}-\mathrm{KAT}_{0}$

10. ETA (Evapotranspirasi Aktual)

Nilai ETA (evapotranspirasi aktual) diperoleh dari hasil:

$\mathrm{ETA}=\mathrm{CH}+|\mathrm{dKAT}|$, jika $\mathrm{CH}<\mathrm{ETC}$.

Jika $\mathrm{CH}>\mathrm{ETC}$, maka ETA = ETc.

11. Defisit

Nilai defisit diperoleh dari hasil:

(D) $=$ ETC - ETA

12. Surplus

Mengisi kolom Surplus (S) yang tidak terjadi defisit (D).

$\mathrm{S}=\mathrm{CH}-\mathrm{ETC}-\mathrm{dKAT}$

\section{Hasil dan Pembahasan}

Kebutuhan air suatu tanaman dapat dihitung berdasarkan jumlah air yang dievapotranspirasikan oleh tanaman itu sendiri (crop evapotranspiration, ETc). Setiap tanaman memiliki koefisien tanaman (crop coefisien) yang akan mempengaruhi nilai ETc yang terjadi. Pada penelitian ini, akan membandingkan nilai neraca air tanaman pada lahan perkebunan kelapa sawit dengan lahan hutan konversi. Hutan konversi merupakan salah satu jenis hutan yang disediakan untuk kegunaan lain misalnya seperti perkebunan, pertanian maupun permukiman. Hutan konversi ini terdapat pada area perkebunan sawit tetapi belum dibuka untuk kebutuhan perkebunan.

Berikut data curah hujan dalam perhitungan menggunakan peluang kejadian metode ranking, untuk data curah hujan selama 10 tahun (2002-2012)..Umumnya peluang kejadian curah hujan terlampaui yang digunakan di bidang pertanian adalah $75 \%(P>75)$.

Tabel 1. Nilai Peluang Curah Hujan 75\% ( $P>75 \%)$

\begin{tabular}{|c|c|}
\hline Bulan & (P>75\%) \\
\hline Jan & 209 \\
\hline Feb & 99 \\
\hline Mar & 202 \\
\hline Apr & 258 \\
\hline Mei & 193 \\
\hline Jun & 124 \\
\hline Jul & 153 \\
\hline Ags & 108 \\
\hline Sep & 140 \\
\hline Okt & 226 \\
\hline Nop & 295 \\
\hline Des & 277 \\
\hline
\end{tabular}

Berdasarkan nilai curah hujan peluang kejadian terlampaui 75\% selama 10 tahun terlihat bahwa curah hujan tertinggi diperoleh pada bulan Nopember yaitu sebesar 295 mm/bulan, sedangkan curah hujan terendah diperoleh pada bulan Februari yaitu sebesar $99 \mathrm{~mm} /$ bulan.

Kemudian dilanjutkan dengan nilai evapotranspirasi tanaman (ETC). Nilai evapotranspirasi acuan ini diperoleh menurut metode empiris Penman - Monteith dengan menggunakan software Cropwat versi 8.0. Berikut disajikan tabel hasil perhitungan evapotranspirasi acuan $\left(\mathrm{ET}_{0}\right)$ sebagai berikut:

Tabel 2. Nilai Evapotranspirasi Acuan (ETo) 


\begin{tabular}{|c|c|c|c|c|c|c|c|}
\hline Bulan & $\begin{array}{c}\text { Min } \\
\text { Temp }\end{array}$ & $\begin{array}{c}\text { Maks } \\
\text { Temp }\end{array}$ & $\begin{array}{c}\text { Kelembaban } \\
\text { Udara }\end{array}$ & Angin & $\begin{array}{c}\text { Penyinaran } \\
\text { Matahari }\end{array}$ & Radiasi & $\mathrm{ET}_{0}$ \\
\hline & $\left({ }^{\circ} \mathrm{C}\right)$ & $\left({ }^{\circ} \mathrm{C}\right)$ & $(\%)$ & $(\mathrm{km} / \mathrm{hr})$ & $($ Jam $)$ & $\left(\mathrm{MJ} / \mathrm{m}^{2} / \mathrm{hr}\right)$ & $(\mathrm{mm} / \mathrm{hr})$ \\
\hline Jan & 26,2 & 26,8 & 87 & 202 & 4,2 & 15,4 & 3,32 \\
\hline Feb & 24,5 & 27,3 & 87 & 206 & 4,8 & 16,8 & 3,52 \\
\hline Mar & 26,1 & 27,3 & 86 & 198 & 5,0 & 17,3 & 3,69 \\
\hline Apr & 26,7 & 27,9 & 87 & 190 & 5,1 & 17,0 & 3,63 \\
\hline Mei & 26,9 & 28,0 & 86 & 178 & 5,7 & 16,9 & 3,64 \\
\hline Jun & 26,7 & 27,8 & 85 & 178 & 5,5 & 16,0 & 3,50 \\
\hline Jul & 26,0 & 27,9 & 84 & 182 & 5,5 & 16,3 & 3,55 \\
\hline Ags & 26,8 & 27,7 & 83 & 190 & 5,8 & 17,6 & 3,85 \\
\hline Sep & 26,4 & 29,2 & 85 & 186 & 4,8 & 16,7 & 3,77 \\
\hline Okt & 26,3 & 26,9 & 87 & 186 & 4,2 & 15,8 & 3,43 \\
\hline Nop & 26,1 & 27,2 & 89 & 190 & 4,4 & 15,7 & 3,31 \\
\hline Des & 25,5 & 26,8 & 89 & 198 & 3,8 & 14,6 & 3,07 \\
\hline Rata2 & 26,2 & 27,6 & 86 & 190 & 4,9 & 16,4 & 3,52 \\
\hline
\end{tabular}

Nilai evapotranspirasi acuan ( $\left.\mathrm{ET}_{0}\right)$ yang diperoleh, terlihat bahwa nilai tertinggi terdapat pada bulan Agustus yaitu sebesar $3,85 \mathrm{~mm} /$ hari sedangkan nilai terendah terdapat pada bulan Desember $3,07 \mathrm{~mm} /$ hari.

Untuk hasil analisis laboratorium dengan menggunakan contoh tanah utuh yang diambil dari 2 titik berbeda di lokasi penelitian pada kedalaman 0-60 cm, didapatkan kapasitas lapang $\left(\theta_{\mathrm{fc}}\right)$ tanah pada lahan kebun sawit sebesar $57,76 \%$ atau $29,43 \mathrm{~mm}$ dan untuk titik layu permanen $\left(\theta_{\text {pwp }}\right)$ tanah sebesar $38,63 \%$ atau $19,68 \mathrm{~mm}$. Sedangkan kapasitas lapang $\left(\theta_{\mathrm{fc}}\right)$ tanah pada lahan hutan konversi sebesar $70,86 \%$ atau $36,1 \mathrm{~mm}$ dan untuk titik layu permanen $\left(\theta_{\text {pwp }}\right)$ tanah sebesar $46,32 \%$ atau 23,6. Dari nilai tersebut terlihat bahwa nilai kapasitas lapang $\left(\theta_{\mathrm{fc}}\right)$ tanah untuk lahan hutan konversi lebih besar dibandingkan dengan kapasitas lapang $\left(\theta_{\mathrm{fc}}\right)$ tanah pada lahan kebun sawit.

Berikut tabel hasil perhitungan neraca air tanaman yang diperoleh dengan memodifikasi neraca air lahan Thorthwaite dan Mather (1957):

Tabel 3. Neraca air tanaman pada lahan kebun sawit

\begin{tabular}{|c|c|c|c|c|c|c|c|c|c|c|c|c|c|c|}
\hline \multirow{2}{*}{ Komp N.A } & \multicolumn{14}{|c|}{ Bulan (mm) } \\
\hline & Jan & Feb & Mar & Apr & Mei & Jun & Jul & Ags & Sep & Okt & Nop & Des & Total & Rata2 \\
\hline $\mathrm{CH}$ & 280 & 206 & 218 & 327 & 267 & 192 & 216 & 156 & 197 & 374 & 359 & 351 & 3143 & 262 \\
\hline CH 75\% & 209 & 99 & 202 & 258 & 193 & 124 & 153 & 108 & 140 & 226 & 295 & 277 & 2284 & 190 \\
\hline $\mathrm{ET}_{0}$ Harian & 3,32 & 3,52 & 3,69 & 3,63 & 3,64 & 3,5 & 3,55 & 3,85 & 3,77 & 3,43 & 3,31 & 3,07 & & \\
\hline Kc Sawit & 0,93 & 0,93 & 0,93 & 0,93 & 0,93 & 0,93 & 0,93 & 0,93 & 0,93 & 0,93 & 0,93 & 0,93 & & \\
\hline ETc Bulanan & 96 & 92 & 106 & 101 & 105 & 98 & 102 & 111 & 105 & 99 & 92 & 89 & 1196 & 100 \\
\hline $\mathrm{CH}-\mathrm{ETC}$ & 113 & 7 & 96 & 157 & 88 & 26 & 51 & -3 & 35 & 127 & 203 & 188 & 1088 & 91 \\
\hline APWL & 0 & 0 & 0 & 0 & 0 & 0 & 0 & -3 & 0 & 0 & 0 & 0 & -3 & 0 \\
\hline KAT & 29 & 29 & 29 & 29 & 29 & 29 & 29 & 27 & 29 & 29 & 29 & 29 & 346 & 29 \\
\hline dKAT & 0 & 0 & 0 & 0 & 0 & 0 & 0 & -2 & 2 & 0 & 0 & 0 & 0 & 0 \\
\hline ETA & 96 & 92 & 106 & 101 & 105 & 98 & 102 & 110 & 105 & 99 & 92 & 89 & 1195 & 100 \\
\hline Defisit & 0 & 0 & 0 & 0 & 0 & 0 & 0 & 1 & 0 & 0 & 0 & 0 & 1 & 0 \\
\hline Surplus & 113 & 7 & 96 & 157 & 88 & 26 & 51 & 0 & 35 & 127 & 203 & 188 & 1091 & 91 \\
\hline
\end{tabular}

Tabel 3 merupakan hasil perhitungan untuk neraca air tanaman di lahan kebun sawit. Dari tabel dapat dilihat bahwa untuk nilai rata-rata curah hujan adalah $262 \mathrm{~mm}$ berdasarkan nilai curah hujan dari Badan Meteorologi Supadio sedangkan menurut perhitungan metode ranking untuk curah hujan peluang kejadian $75 \%$ adalah sebesar $190 \mathrm{~mm}$. Untuk nilai evapotranspirasi potensial (ETc) rata-rata 
di lahan kebun sawit adalah $100 \mathrm{~mm}$, sedangkan evapotranspirasi aktual (ETA) adalah sebesar 100 $\mathrm{mm}$. Kemudian untuk nilai kandungan air tanah (KAT) rata-ratanya adalah $29 \mathrm{~mm}$ dan untuk nilai rata-rata surplus air adalah $91 \mathrm{~mm}$.

Tabel 4. Neraca air tanaman pada lahan hutan konversi

\begin{tabular}{|c|c|c|c|c|c|c|c|c|c|c|c|c|c|c|}
\hline \multirow{2}{*}{ Komp N.A } & \multicolumn{14}{|c|}{ Bulan (mm) } \\
\hline & Jan & Feb & Mar & Apr & Mei & Jun & Jul & Ags & Sep & Okt & Nop & Des & Total & Rata2 \\
\hline $\mathrm{CH}$ & 280 & 206 & 218 & 327 & 267 & 192 & 216 & 156 & 197 & 374 & 359 & 351 & 3143 & 262 \\
\hline CH 75\% & 209 & 99 & 202 & 258 & 193 & 124 & 153 & 108 & 140 & 226 & 295 & 277 & 2284 & 190 \\
\hline $\mathrm{ET}_{0}$ Harian & 3,32 & 3,52 & 3,69 & 3,63 & 3,64 & 3,5 & 3,55 & 3,85 & 3,77 & 3,43 & 3,31 & 3,07 & & \\
\hline Kc Hutan & 0,89 & 0,89 & 0,89 & 0,89 & 0,89 & 0,89 & 0,89 & $0,8 \mathrm{~s}$ & 0,89 & 0,89 & 0,89 & 0,89 & & \\
\hline ETc Bulanan & 92 & 88 & 102 & 97 & 100 & 93 & 98 & 106 & 101 & 95 & 88 & 85 & 1144 & 95 \\
\hline $\mathrm{CH}-\mathrm{ETC}$ & 117 & 11 & 100 & 161 & 93 & 31 & 55 & 2 & 39 & 131 & 207 & 192 & 1140 & 95 \\
\hline APWL & 0 & 0 & 0 & 0 & 0 & 0 & 0 & -11 & 0 & 0 & 0 & 0 & -11 & -1 \\
\hline KAT & 36 & 36 & 36 & 36 & 36 & 36 & 36 & 28 & 36 & 36 & 36 & 36 & 424 & 35 \\
\hline dKAT & 0 & 0 & 0 & 0 & 0 & 0 & 0 & -8 & 8 & 0 & 0 & 0 & 0 & 0 \\
\hline ETA & 103 & 99 & 114 & 109 & 113 & 105 & 110 & 116 & 113 & 106 & 99 & 95 & 1282 & 107 \\
\hline Defisit & -11 & -11 & -12 & -12 & -13 & -12 & -12 & -10 & -12 & -11 & -11 & -10 & -138 & -11 \\
\hline Surplus & 117 & 11 & 100 & 161 & 93 & 31 & 55 & 13 & 39 & 131 & 207 & 192 & 1151 & 96 \\
\hline
\end{tabular}

Tabel 4 merupakan hasil perhitungan untuk neraca air tanaman di lahan hutan konversi. Isi tabel menunjukkan bahwa untuk nilai rata-rata curah hujan adalah $262 \mathrm{~mm}$ berdasarkan nilai curah hujan dari Badan Meteorologi Supadio sedangkan menurut perhitungan metode ranking untuk curah hujan peluang kejadian $75 \%$ adalah sebesar $190 \mathrm{~mm}$. Dari nilai kedua curah hujan ini sama untuk dikedua lahan. Untuk nilai evapotranspirasi potensial (ETc) rata-rata di lahan hutan konversi adalah $95 \mathrm{~mm}$ sedangkan evapotranspirasi aktual (ETA) adalah sebesar $107 \mathrm{~mm}$. Kemudian untuk nilai kandungan air tanah (KAT) rata-ratanya adalah $35 \mathrm{~mm}$ dan untuk nilai rata-rata surplus air adalah $96 \mathrm{~mm}$.

Dibawah ini merupakan grafik dari perbandingan nilai evapotranspirasi pontensial di lahan kebun sawit dengan lahan hutan konversi.

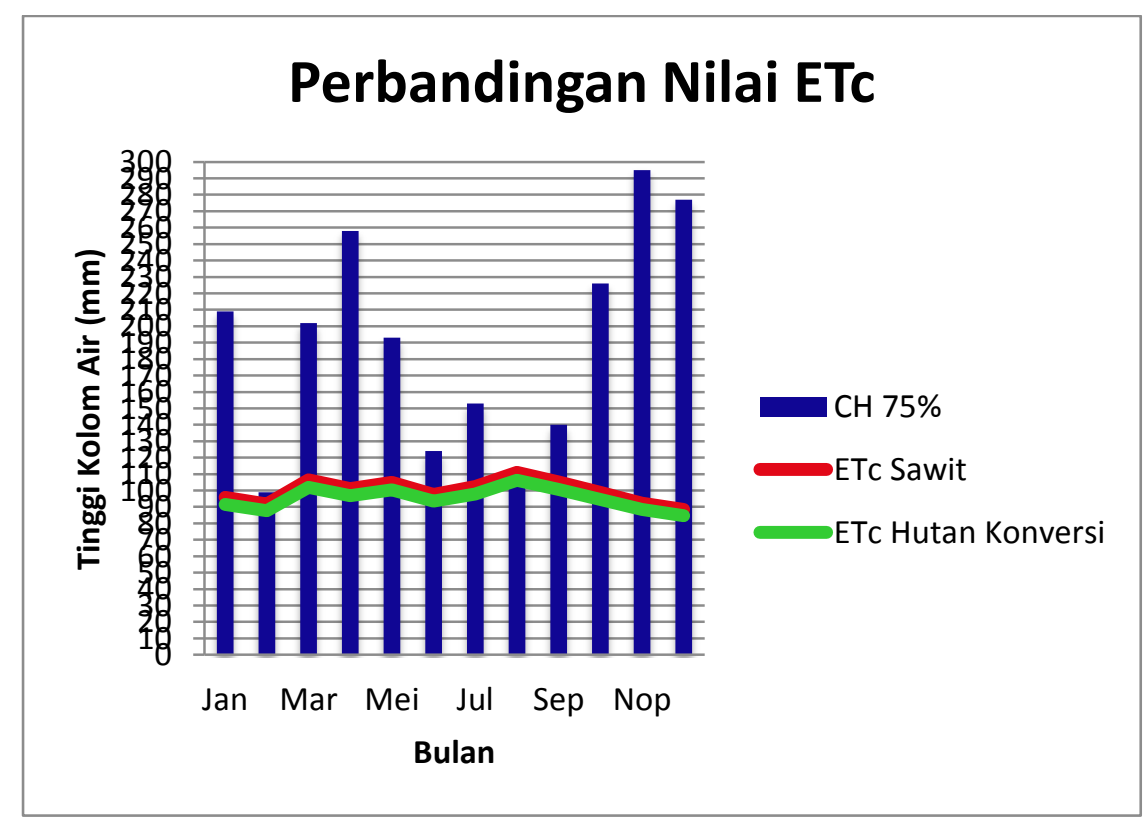

Gambar 1. Perbandingan nilai ETc di lahan kebun sawit dan hutan konversi 
Setiap tanaman memiliki koefisien tanaman (crop coefisien) yang akan mempengaruhi nilai ETc yang terjadi. Nilai kc rata-rata untuk jenis hutan adalah 0,87-0,89 (Shuttleworth, 1988; dalam Van de Wert, 1994; dalam Widodo, 2010), sedangkan untuk tanaman kelapa sawit adalah sebesar 0,93 untuk tanaman kelapa sawit yang berumur lebih dari 7 tahun (Harahap, 1999; dalam Widodo, 2010).

Kebutuhan air untuk tanaman dapat didefinisikan sebagai jumlah air yang diperlukan untuk memenuhi kehilangan air melalui evapotranspirasi dari tanaman (Pasaribu dkk, 2012). Dari hasil perhitungan neraca air tanaman, didapatkan rata-rata nilai evapotranspirasi tanaman (ETC) yang terjadi diperkebunan kelapa sawit adalah $100 \mathrm{~mm} /$ bulan atau setara dengan $1.196 \mathrm{~mm} /$ tahun dengan perhitungan persentase sebesar $52,36 \%$ dari curah hujan tahunan peluang $75 \%$. Nilai tersebut lebih besar bila dibandingkan dengan evapotranspirasi tanaman (ETC) yang terjadi pada lahan hutan konversi yang rata-rata $95 \mathrm{~mm} /$ bulan atau setara dengan $1.144 \mathrm{~mm} /$ tahun dengan persentasi sebesar $50,11 \%$ dari curah hujan tahunan peluang $75 \%$. Perubahan tutupan lahan ini mengakibatkan adanya peningkatan kebutuhan air tanaman sebesar $52 \mathrm{~mm} / \mathrm{tahun}$, dan akan mempengaruhi ketersediaan air yang ada pada lahan tersebut.

Koefisien evapotranspirasi menunjukkan bahwa semakin tinggi laju evapotranspirasi pada periode tertentu maka semakin berkurang pula cadangan air tanah dan bertambahnya kedalaman muka air tanah pada periode tersebut. Evapotranspirasi punya pengaruh yang penting terhadap besarnya ketersediaan air tanah, semakin besar terjadinya evapotranspirasi maka akan semakin besar air yang keluar dari sistem tanah. Menurut Harahap dan Darmosarkoro (1999), sumber utama pengeluaran air dari sistem tanah adalah proses evapotranspirasi, tingginya evapotranspirasi dapat mengubah kondisi muka air tanah secara cepat (Pasaribu dkk, 2012).

Besarnya nilai evapotranspirasi (ETC) di lahan perkebunan kelapa sawit daripada lahan hutan konversi dipengaruhi oleh beberapa faktor selain faktor iklim mikro dan faktor tanah. Faktor tanaman juga turut mempengaruhi seperti jenis tanaman, derajat penutupannya, struktur tanaman, stadia perkembangan sampai masak, keteraturannya serta banyaknya stomata.

Selanjutnya untuk kandungan air tanah (KAT) menunjukan kapasitas simpan dari zona perakaran. Lahan perkebunan sawit memiliki kandungan air tanah lebih rendah dibandingkan dengan hutan konversi. Hal ini juga dipengaruhi oleh sifat tanaman kelapa sawit yang membutuhkan banyak air. Kandungan air tanah (KAT) dalam tabel 3 menunjukkan nilai KAT pada kebun sawit lebih kecil yaitu $346 \mathrm{~mm}$ dibandingkan dengan tabel 4 menunjukkan nilai KAT pada hutan konversi yaitu 424 $\mathrm{mm}$. Hal ini terlihat bahwa tanaman kelapa sawit memerlukan air yang banyak ("rakus air"). Dapat juga dibuktikan dari nilai kc (crop coefisien) tanaman kelapa sawit yang lebih besar (Tabel 4.8) dibandingkan dengan kc hutan konversi (Tabel 4.9). Pengurangan kandungan air tanah pada kebun sawit dan hutan konversi terjadi selama 1 bulan yaitu bulan Agustus.

Selain nilai koefisien konsumtif tanaman (kc) yang mempengaruhi nilai kandungan air tanah (KAT), tetapi ada faktor lain juga yang mempengaruhinya seperti infiltrasi. Infiltrasi ini merupakan proses aliran air (umumnya berasal dari curah hujan) yang masuk ke dalam tanah (gerakan air ke arah vertikal). Jika air hujan meresap ke dalam tanah maka kadar lengas tanah meningkat hingga mencapai kapasitas lapang. Pada kondisi kapasitas lapang air yang masuk menjadi perkolasi dan mengisi daerah yang lebih rendah energi potensialnya sehingga mendorong terjadinya aliran antara (interflow) dan aliran bawah permukaan lainnya (base flow). Air yang berada pada lapisan air tanah jenuh dapat pula bergerak ke segala arah (ke samping dan ke atas) dengan gaya kapiler atau dengan bantuan penyerapan oleh tanaman melalui tudung akar.

Adapun beberapa faktor internal dan eksternal yang mempengaruhi laju infiltrasi adalah seperti (Achmad, 2011):

1. Tinggi genangan air di atas permukaan tanah dan tebal lapisan tanah yang jenuh.

2. Kadar air atau lengas tanah, dengan adanya vegetasi atau tanaman pada suatu lahan akan dapat meningkatkan kadar air kapasitas lapang kadar air maksimum. Hal ini disebabkan oleh pemberian mulsa hasil pangkasan yang menjadi bahan organik, dimana diketahui bahan organik dapat mengikat air sampai enam kali beratnya sendiri sehingga kemampuan infiltrasinya tinggi (Hakim dkk, 1986; dalam Purnama dkk, 2012).

3. Pemadatan tanah oleh curah hujan 
4. Penyumbatan pori tanah mikro oleh partikel tanah halus seperti bahan endapan dari partikel liat

5. Pemadatan tanah oleh manusia dan hewan akibat traffic line oleh alat olah

6. Struktur tanah

7. Kondisi perakaran tumbuhan baik akar aktif maupun akar mati (bahan organik)

8. Proporsi udara yang terdapat dalam tanah (porositas), pada porositas yang tinggi maka tanah akan dapat menyimpan air dalam jumlah yang besar, sehingga air hujan yang datang akan dapat meresap atau mengalami infiltrasi dengan cepat tanpa terjadinya aliran permukaan (Suryatmojo, 2006; dalam Purnama dkk, 2012)

9. Topografi atau kemiringan lahan

10. Intensitas hujan

11. Kekasaran permukaan tanah

12. Kualitas air yang akan terinfiltrasi

13. Suhu udara tanah dan udara sekitar

Berikut grafik perbandingan antara nilai surplus air di lahan kebun sawit dengan lahan hutan konversi.

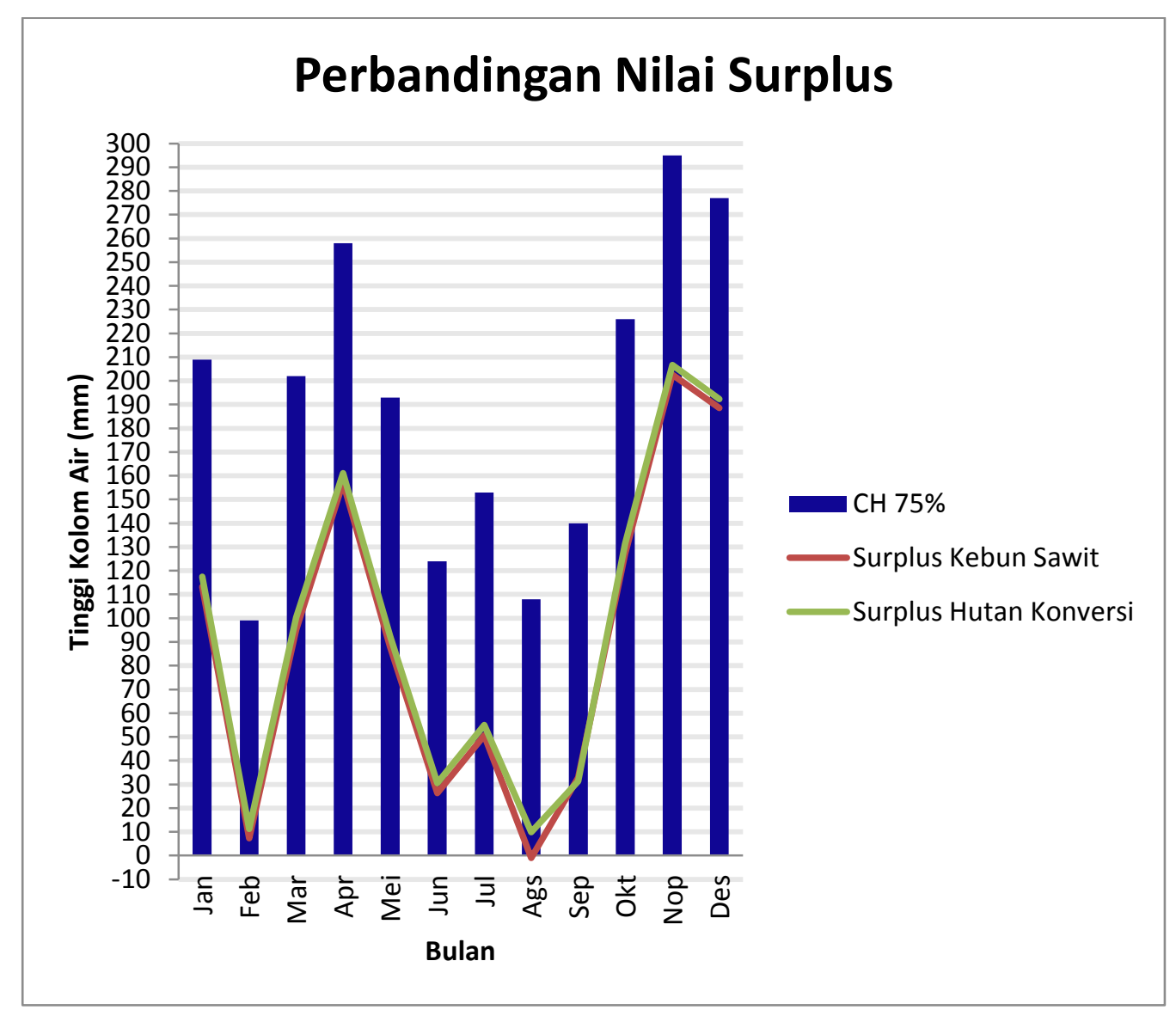

Gambar 2. Perbandingan nilai surplus di lahan kebun sawit dan hutan konversi

Gambar di atas menggambarkan perbedaan antara lahan hutan konversi dengan lahan yang sudah dikonversi menjadi perkebunan kelapa sawit. Perubahan ini menyebabkan penurunan nilai surplus air yang ada pada lahan tersebut. Penurunan surplus ini sekitar $59 \mathrm{~mm}$ per tahun, dapat dilihat dari nilai surplus pada hutan konversi sebesar $1.151 \mathrm{~mm}$ per tahun sedangkan pada lahan perkebunan $1.091 \mathrm{~mm}$ per tahun, dan ini akan mempengaruhi debit yang terjadi. Penurunan debit berarti pengurangan nilai air tersedia yang mampu dimanfaatkan oleh stakeholder pengguna air, dan salah satunya adalah sektor domestik. 
Curah hujan yang efektif pada periode waktu tertentu menentukan kedalaman muka air tanah melalui peubah infiltrasi. Perubahan kedalaman muka air tanah sangat dipengaruhi oleh kondisi cadangan air tanah, dimana semakin banyak cadangan air tanah dalam sistem tanah tersebut maka semakin tinggi kondisi muka air tanah pada periode tersebut.

Bulan-bulan dengan curah hujan efektif yang tinggi dan jumlah air infiltrasi yang tinggi menyebabkan kedalaman muka air tanah yang tinggi. Di lain pihak, periode dengan curah hujan efektif dan jumlah air infiltrasi yang rendah menyebabkan kedalaman muka air tanah yang rendah. Pada area tanaman kelapa sawit dewasa, kedalaman muka air tanah berhubungan dengan jumlah curah hujan efektif dan jumlah air infiltrasi.

Secara umum dapat dilihat bahwa fluktuasi perubahan kedalaman muka air tanah dengan cadangan air tanah memiliki fluktuasi yang mirip. Perubahan tersebut tergantung besar kecilnya curah hujan efektif dan evapotranspirasi pada area tersebut. Harahap dan Darmosarkoro (1999) dalam Pasaribu dkk (2012), menyatakan curah hujan efektif dan air infiltrasi merupakan sumber air atau pengisian. Peningkatan curah hujan efektif akan meningkatkan kedalaman muka air tanah. Konservasi permukaan tanah dapat mengurangi kehilangan air melalui air limpasan dan evaporasi permukaan tanah.

Maka untuk menjamin ketersediaan air di lapangan selama periode pertumbuhan tanaman sawit dan juga lingkungan sekitar kawasan perkebunan serta agar tetap mampu mempertahankan fungsi lahan gambut untuk aspek konservasi dan mencegah degradasi lahan gambut, maka langkah yang dilakukan oleh manajemen perkebunan adalah dengan mempertahankan wilayah konservasi sebagai penampung alami (water catchment area) dan membuat embung besar.

Hal ini sesuai dengan penelitian Rusmayadi (2011) bahwa dengan tetap mempertahankan wilayah konservasi sebagai penampungan alami dan membuat embung besar yang luasnya puluhan hektar maka pada musim kemarau pun masih dapat mengalirkan air. Di atas merupakan salah satu contoh kasus dari upaya konservasi yang telah dilakukan oleh perkebunan kelapa sawit. Jika perkebunan - perkebunan sawit yang sudah lama keberadaannya melakukan hal yang sama, maka ketersediaan air akan menjadi lebih terjamin. Seandainya, hal yang dilakukan oleh perkebunan sawit tersebut dapat menjadi model untuk menjembatani agrobisnis dengan upaya konservasi, niscaya konservasi secara nasional akan menjadi lebih baik.

Jadi kebun sawit selain sebagai tanaman yang bernilai ekonomis tinggi, sumber pendapatan, lapangan pekerjaan, pendapatan ekspor non migas, salah satu sembako dan juga sebagai produksi oksigen $\left(\mathrm{O}_{2}\right)$ Di samping itu, perkebunan kelapa sawit juga memiliki kemampuan penyerapan emisi karbon dioksida $\mathrm{CO}_{2}$ yang tinggi, ini sangat berguna dalam mengurangi konsentrasi $\mathrm{CO}_{2}$ di udara yang merupakan gas rumah kaca yang menyebabkan pemanasan global yang berdampak pada perubahan iklim di bumi (Rusmayadi, 2011).

\section{Kesimpulan}

Berdasarkan hasil dari analisa yang dijelaskan pada bab sebelumnya, maka dapat diambil kesimpulan sebagai berikut:

1. Dari hasil perhitungan neraca air tanaman, didapatkan rata-rata nilai evapotranspirasi tanaman (ETc) yang terjadi diperkebunan kelapa sawit adalah $100 \mathrm{~mm} /$ bulan. Nilai tersebut lebih besar bila dibandingkan dengan evapotranspirasi tanaman (ETc) yang terjadi pada lahan hutan konversi yang rata-ratanya $95 \mathrm{~mm} /$ bulan. Evapotranspirasi ini mempunya pengaruh yang penting terhadap besarnya ketersediaan air tanah, semakin besar terjadinya evapotranspirasi maka akan semakin besar air yang keluar dari sistem tanah.

2. Besarnya nilai evapotranspirasi (ETC) dipengaruhi oleh beberapa faktor selain faktor iklim mikro dan faktor tanah. Faktor tanaman juga turut mempengaruhi seperti jenis tanaman, derajat penutupannya, struktur tanaman, stadia perkembangan sampai masak, keteraturannya serta banyaknya stomata.

3. Berdasarkan nilai surplus air, lahan hutan konversi memiliki nilai surplus lebih besar jika dibandingkan dengan lahan perkebunan kelapa sawit. nilai surplus pada hutan konversi sebesar $1.151 \mathrm{~mm}$ per tahun sedangkan pada lahan perkebunan $1.091 \mathrm{~mm}$ per tahun. Curah hujan yang 
efektif pada periode waktu tertentu menentukan kedalaman muka air tanah melalui peubah infiltrasi. Perubahan kedalaman muka air tanah sangat dipengaruhi oleh kondisi cadangan air tanah, dimana semakin banyak cadangan air tanah dalam sistem tanah tersebut maka semakin tinggi kondisi muka air tanah pada periode tersebut.

\section{Ucapan Terima Kasih}

Penulis menyampaikan terima kasih kepada seluruh pihak yang membantu dalam kelancaran penelitian ini dan telah banyak memberikan bantuan, masukkan, koreksi serta saran yang penulis rasakan manfaatnya. Bapak Ir. H. Asrifin Aspan, MS dan bapak Robby Irsan, ST, Msi selaku dosen pembimbing. Ibu Ir. Rita Hayati, Msi dan Bapak Winardi Yusuf, ST, MT selaku dosen penguji. Serta ucapan terima kasih kepada Pimpinan PT. Rezeki Kencana beserta staf dan jajarannya.

\section{Referensi}

Achmad, M. 2011. Buku Ajar Hidrologi Teknik. Universitas Hasanuddin. Makasar.

Badan Pusat Statistik (BPS). 2010. Kubu Raya Dalam Angka Kubu Raya Regency In Figures 2010. BPS Kabupate Kubu Raya. 1102001.6112.

Krisnohadi, A. 2011. Analisis Pengembangan Lahan Gambut Untuk Tanaman Kelapa Sawit Kabupaten Kubu Raya. Vol 1, Juni 2011, hal 1-7.

Pasaribu, H., Mulyadi, A. dan Tarumun, S. 2012. Neraca Air Di Perkebunan Kelapa Sawit Di PPKS Sub Unit Kalianta Kabun Riau. Jurnal Ilmu Lingkungan. ISSN 1978-5283.

Purnama, S., Trijuni, S., Hanafi, F., Auliya, T. dan Razali, R. 2012. Analisis Neraca Air Di DAS Kupang Dan Sengkarang. Magister Perencanaan dan Pengelolaan Pesisir dan Daerah Aliran Sungai (MPPDAS). Program S-2 Geografi. Fakultas Geografi Universitas Gadjah Mada. Yogyakarta.

Rusmayadi, G. 2011. Dinamika Kandungan Air Tanah Di Areal Perkebunan Kelapa Sawit Dan Karet Dengan Pendekatan Neraca Air Tanaman. Fakultas Pertanian UNLAM. Vol. 18. HIm 86-92.

Widodo, I.S dan Dasanto, B.D. 2010. Estimasi Nilai Ekonomi Lingkungan Perkebunan Kelapa Sawit Ditinjau Dari Neraca Air Tanaman Kelapa Sawit Studi Kasus Perkebunan Kelapa Sawit Di Kecamatan Dayun. Institut Pertanian Bogor: Bogor. 